\title{
Determination and Comparison of Different Photovoltaic Module Temperature Models for Kuching, Sarawak
}

\author{
Abdul Qayoom Jakhrani ${ }^{\text {a, }}$, Al-Khalid Othman ${ }^{\mathrm{a}}$, Andrew Ragai Henry Rigit ${ }^{\mathrm{a}}$ and Saleem Raza Samo ${ }^{\mathrm{b}}$ \\ ${ }^{\text {a }}$ Faculty of Engineering, Universiti Malaysia Sarawak, 94300, Kota Samarahan, Sarawak, Malaysia \\ ${ }^{\mathrm{b}}$ Department of Energy and Environment Engineering, Quaid-e-Awam University of Engineering, Science and Technology \\ Nawabshah, Sindh, Pakistan \\ "Email: aqunimas@hotmail.com
}

\begin{abstract}
This paper presents the approach of the different models that used to predict the module temperature, which is one of the most important factors responsible for lowering the performance of PV modules. The suitability of the models for PV module temperature prediction was examined in order to assess the anticipated behavior of module temperature increase with respect to ambient temperature and solar radiation. A total of 16 models has been selected and investigated by employing the monthly mean daily meteorological data of Kuching, Sarawak. It is revealed that most models exposed analogous tendency of module temperature and solar radiation intensity. However, their magnitude was quite dissimilar under constant solar radiation and ambient temperature conditions. This variation may be due to the use of different variables, climatic conditions, configuration of $P V$ modules and approach used by various researchers.
\end{abstract}

Keywords- photovoltaic modules; cell temperature models; PV systems

\section{INTRODUCTION}

Photovoltaic module operating temperature is one of the most important parameters for the evaluation of long term performance of PV systems, as it modifies the power output and system efficiency. Its affect varies with characteristics of module encapsulating material, thermal absorption and dissipation properties, types of PV cells, configuration, installation and operating point of module, and climatic conditions of locality such as solar irradiation level, ambient temperature and wind speed [1-3].

Photovoltaic module performance or efficiency is usually inversely proportional to the operating temperature of cell. Two challenging factors are playing the conflicting role in the power output of PV modules. Firstly, as temperature increases, the band gap of the intrinsic semiconductor shrinks, the open circuit voltage $\left(\mathrm{V}_{\mathrm{oc}}\right)$ decreases following the $\mathrm{p}-\mathrm{n}$ junction voltage temperature, which contains diode factor. It is equivalent to the charge $(\mathrm{q})$ divided by the product of cell temperature $(\mathrm{T})$ and a constant $(\mathrm{k})$, in which the $\mathrm{q}$ is electronic charge $\left[1.602 \times 10^{-19}\right.$ coulomb] $(1 \mathrm{C}=1 \mathrm{~A} \mathrm{~s}), \mathrm{k}$ is Boltzmann's constant $\left[1.381 \times 10^{-23} \mathrm{~J} / \mathrm{K}\right]$ and $\mathrm{T}$ is cell temperature $\left({ }^{\circ} \mathrm{C}\right)$. Hence, the PV cells have a negative temperature coefficient of open circuit voltage $\left(\beta \mathrm{V}_{\mathrm{oc}}\right)$. Likewise, that caused a lower power output at a given photocurrent, because the charge carriers are liberated at a lower potential. Thus, the reduction in $\mathrm{V}_{\mathrm{oc}}$ results lower theoretical max. power $\left(\mathrm{P}_{\max }=\mathrm{I}_{\mathrm{sc}}{ }^{*} \mathrm{~V}_{\mathrm{oc}}\right)$ at a particular short-circuit current $\mathrm{I}_{\mathrm{sc}}$. Secondly, as temperature increases again the band gap of the inherent semiconductor shrinks, which results more absorption of incident energy. The greater percentage of the incident light has sufficient energy to raise charge carriers from the valence band to the conduction band. A larger photocurrent result the increase of $\mathrm{I}_{\mathrm{sc}}$ at a definite solar insolation. The PV cells have a positive temperature coefficient of short circuit current $\left(\alpha \mathrm{I}_{\mathrm{sc}}\right)$. This effect alone would raise the theoretical maximum power by the relationship above [4 -7]. Consequently, at a fixed solar radiation level increasing temperature leads to decreased open circuit voltage and slightly increased short circuit current, eventually it reduces the power output [6]. Thus it requires lowering the operating temperature of modules but with high irradiance. Since, the temperature of cells is very difficult to measure, because the cells are firmly enclosed for moisture protection. Therefore, in most cases, the back side temperature of a PV module is commonly measured, and assumed that the junction temperatures $\left(\mathrm{T}_{\mathrm{j}}\right)$ of cells are the same as that of its back surface temperature [2]. Besides back side of temperature, some researchers are using the average value of the surface temperatures of the both the front side and the back side of PV module as the junction temperatures $\left(T_{j}\right)$ of cells [4]. Many studies demonstrated that the models give satisfactory results, but they are not suitable for all conditions where the ventilation system is poor. However, the accuracy of most models is questionable because the environmental and geographical conditions of different areas are totally dissimilar from the specified conditions as assumed by the models. Unfortunately, a small number of studies have been conducted in equatorial regions where the environmental factors are extensively different from the climate conditions of high latitude areas [2]. The reliable quantified data from the hot and humid climate region such as the Southeast Asian region is very difficult to obtained, although the data is available for various parts of the 